\title{
MOUNTAIN LADY'S-SLIPPER IN SASKATCHEWAN
}

VERNON L. HARMS, The W.P. Fraser Herbarium, University of Saskatchewan, Saskatoon, Saskatchewan, S7N OW0, LAWRENCE I. BINKLEY, 112 Cypress Street, Maple Creek, Saskatchewan, SON 1 NO and GEORGE F. LEDINGHAM, Herbarium, Department of Biology, University of Regina, Regina, Saskatchewan. S4S OA2

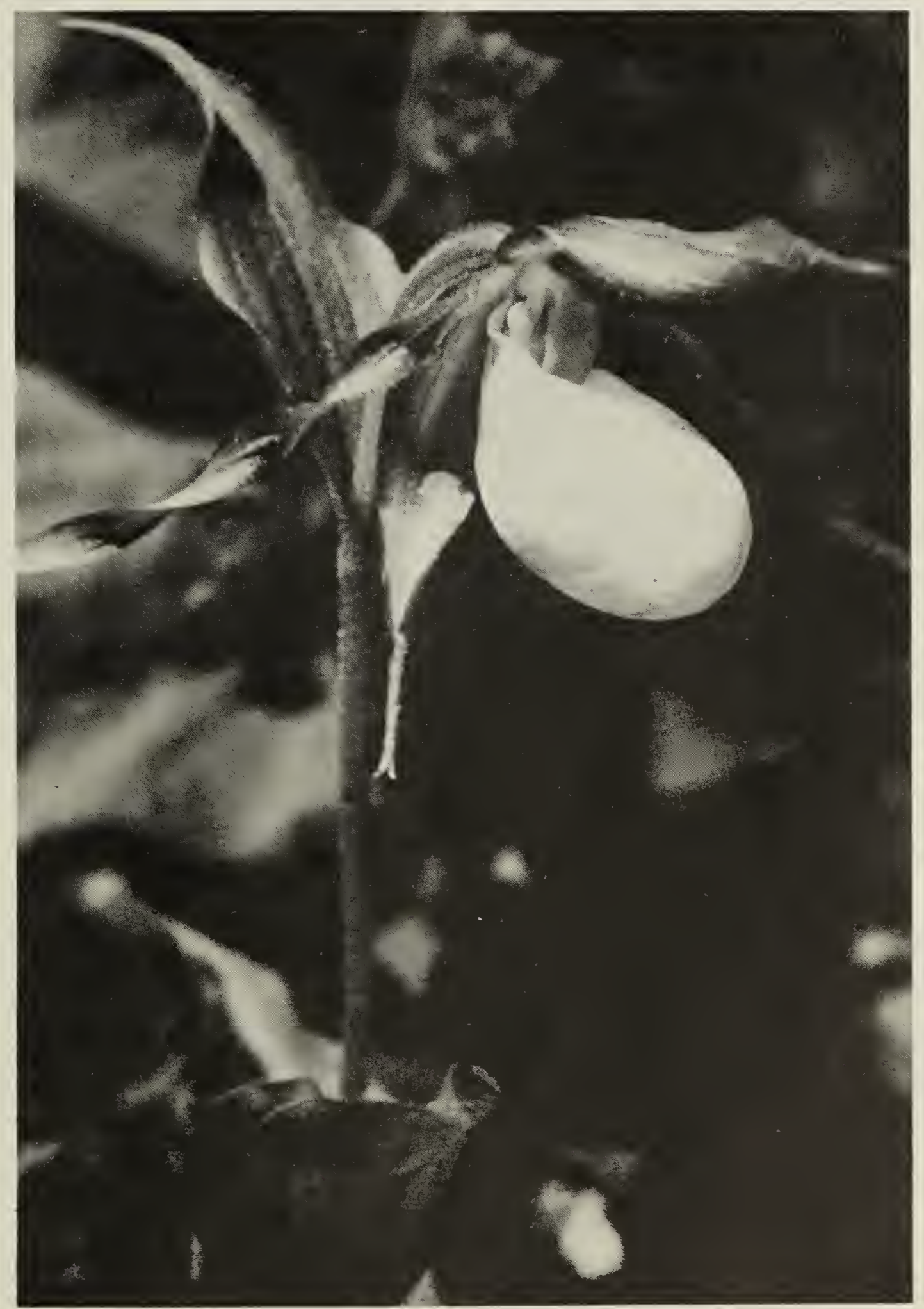

Figure 1. The Mountain Lady's-slipper in the Cypress Hills. (Photograph by Lawrence Binkley). 
On 17 June, 1984, Florence Quick discovered a single flowering orchid of the Mountain Lady's-slipper (Cypripedium montanum Dougl.) growing in a wooded cottage area west of Loch Leven, in Cypress Hills Provincial Park in southwestern Saskatchewan (Fig. 1). This find was reported to Binkley, who tentatively identified it, sketched and described it in detail, and contacted Ledingham and Harms. This plant was observed throughout the rest of the 1984 summer season by Binkley and Mary Helmerson. The single flower remained in full blossom for an astonishing three weeks, perhaps because fertilization was not achieved for this isolated plant. Subsequently, the capsule never fully developed nor expanded. The stem stayed mostly green until nearly mid-September, with the leaves and dried flower parts remaining attached. On 20 September, 1984, the upper stem portion was clipped for a voucher specimen (G.F. Ledingham and L.I. Binkley no. 8929, SASK), which, together with the color photographs of the plant in the flower stage, serve to document this new provincial record.
This orchid species of moist woods in the northern Rocky and Cascade Mountains was previously known eastward to Waterton $\mathrm{Na}$ tional Park in southwestern Alberta, and to the Big Belt, Little Belt, and Bighorn Mountains of central and south-central Montana and northcentral Wyoming (Fig. 3). ${ }^{5}{ }^{6}$ It was never previously recorded for anywhere in Saskatchewan nor for the Cypress

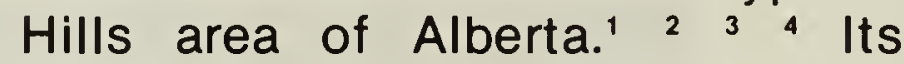
discovery in the Saskatchewan Cypress Hills represents an interesting and significant range extension. Its occurrence here parallels that of various other "cordilleran" plant species [e.g. Lance-leaved Spring Beauty (Claytonia lanceolata), Black-fruited Hawthron (Crataegus douglasii), Mountain Bladder Fern (Cystopteris montanum), Woodland Star-flower (Lithophragma bulbifera), Large Yellow Monkey-flower (Mimulus guttatus), Narrow-leaved Spring Beauty (Montia linearis), American Pinesap (Monotropa hypopitys), Pine Drops (Pterospora andromedea), and Lodgepole Pine (Pinus contorta)].

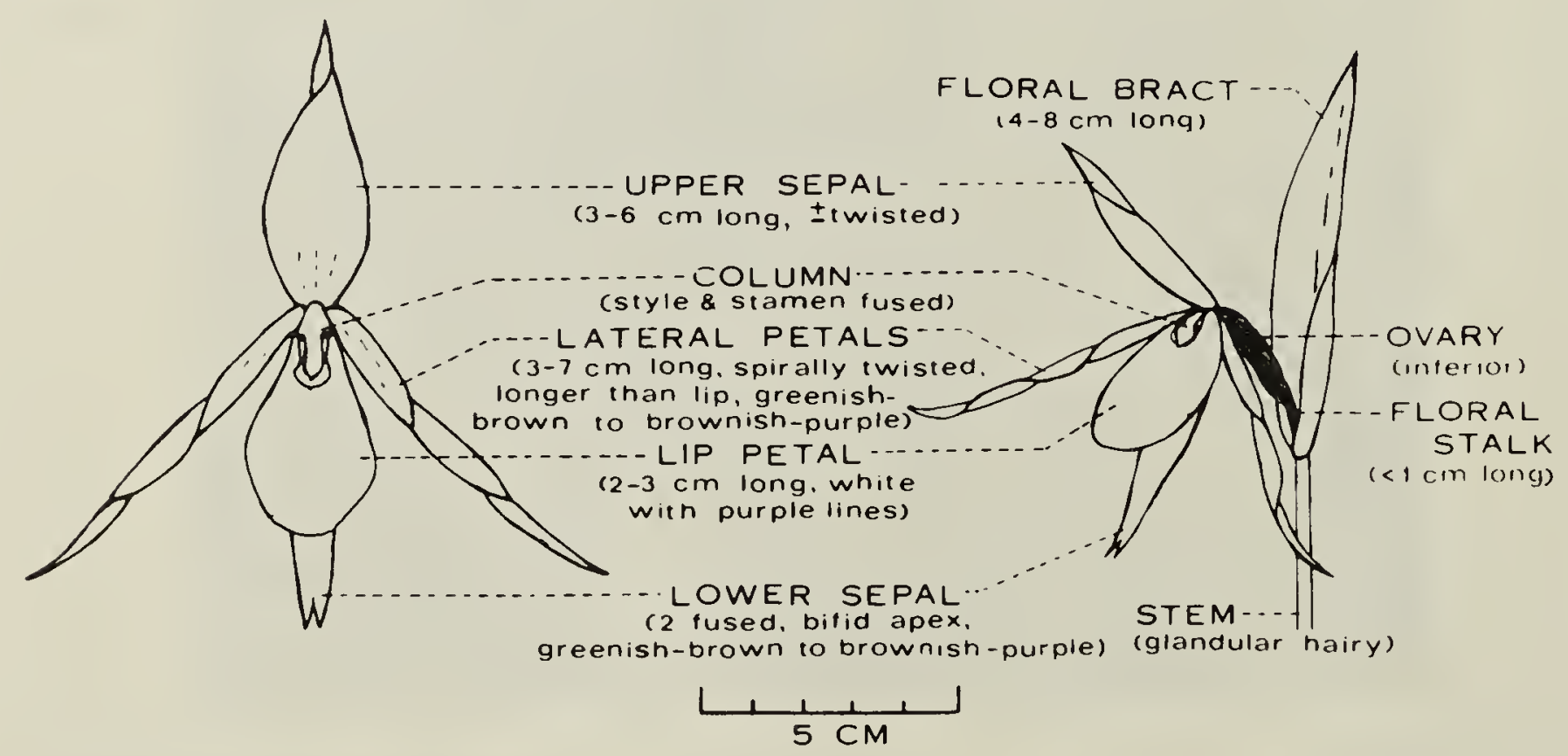

Figure 2. Flower structure of the Mountain Lady's-slipper with indication of diagnostic features. 


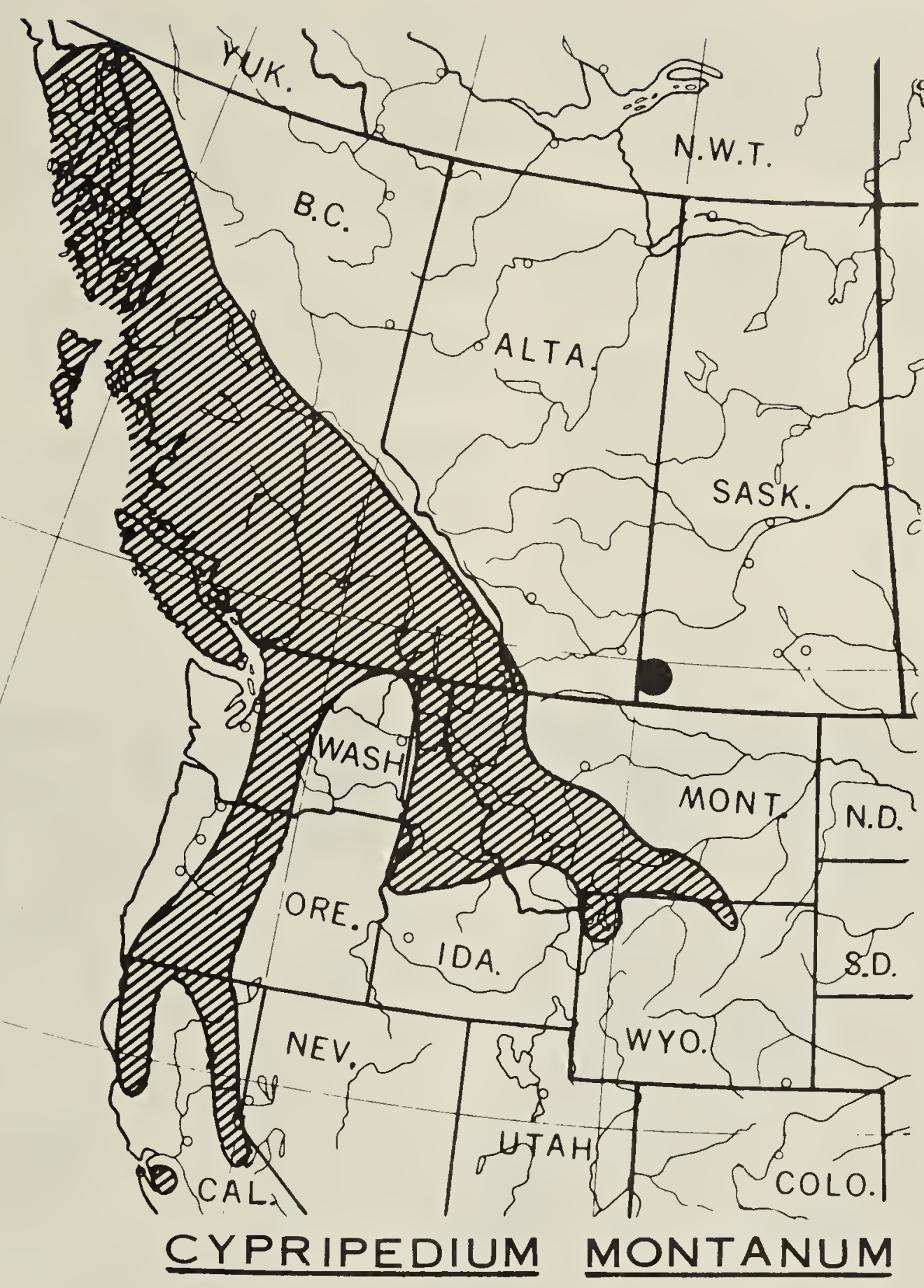

Figure 3. Distribution of the Mountain Lady's-slipper (indicated by hatching, with the new Cypress Hills locality shown by a solid dot). ${ }^{5}$

The Mountain Lady's-slipper can be distinguished from the similar Small White (or Northern, or Sparrow's-egg) Lady's-slipper (Cypripedium passerinum Dougl.) primarily on the bases of: (1) its luminescent white lip-pouch longer than $2 \mathrm{~cm}$ and usually purple-lined below; (2) its sepals and lateral petals over $3 \mathrm{~cm}$ long, distinctly longer than the lip, greenish- to purplish-brown, and twisted; (3) its stems densely grandular-hairy (not just fuzzyvillous); (4) its fruiting stalk $1 \mathrm{~cm}$ long or less; and (5) its stem often taller than $3 \mathrm{dm}$. (Fig. 2). ${ }^{5}{ }^{6}$ In its stem and leaf characteristics, as well as in the shapes and sizes of its flower parts, the Mountain Lady's-slipper actually seems most similar to the Yellow Lady's-slipper (C. calceolus L.) although contrasting sharply from it in flower color.

The documented occurrence in this area of one individual of this species suggests that, if searched for, more plants of the Mountain 
Lady's-slipper might be found in the Saskatchewan and Alberta Cypress Hills, although the species is probably very rare here.

'BREITUNG, A.J. 1954. A botanical survey of the Cypress Hills. The Canadian Field-Naturalist 68:55-92.

${ }^{2}$ BREITUNG, A.J. 1957. Annotated catalogue of the vascular flora of Saskatchewan. American Midland Naturalist 58:1-72.
${ }^{3}$ FISHER, R.M. 1980. The orchids of the Cypress Hills. O. Pall, Calgary. 39 pp.

"HARMS, V.L. 1974. The native lady'sslipper orchids of Saskatchewan. Blue Jay 32:64-74.

${ }^{5}$ LUER, C.A. 1975 . The native orchids of the United States and Canada ex. cluding Florida. New York Bot. Gard., Bronx, N.Y. 361 pp.

${ }^{6}$ SCOGGAN, H.J. 1978. Flora of Canada, Part 2 - Pteridophyta, Gymnospermae, Monocotyledoneae. National Mus. Canada, Ottawa.

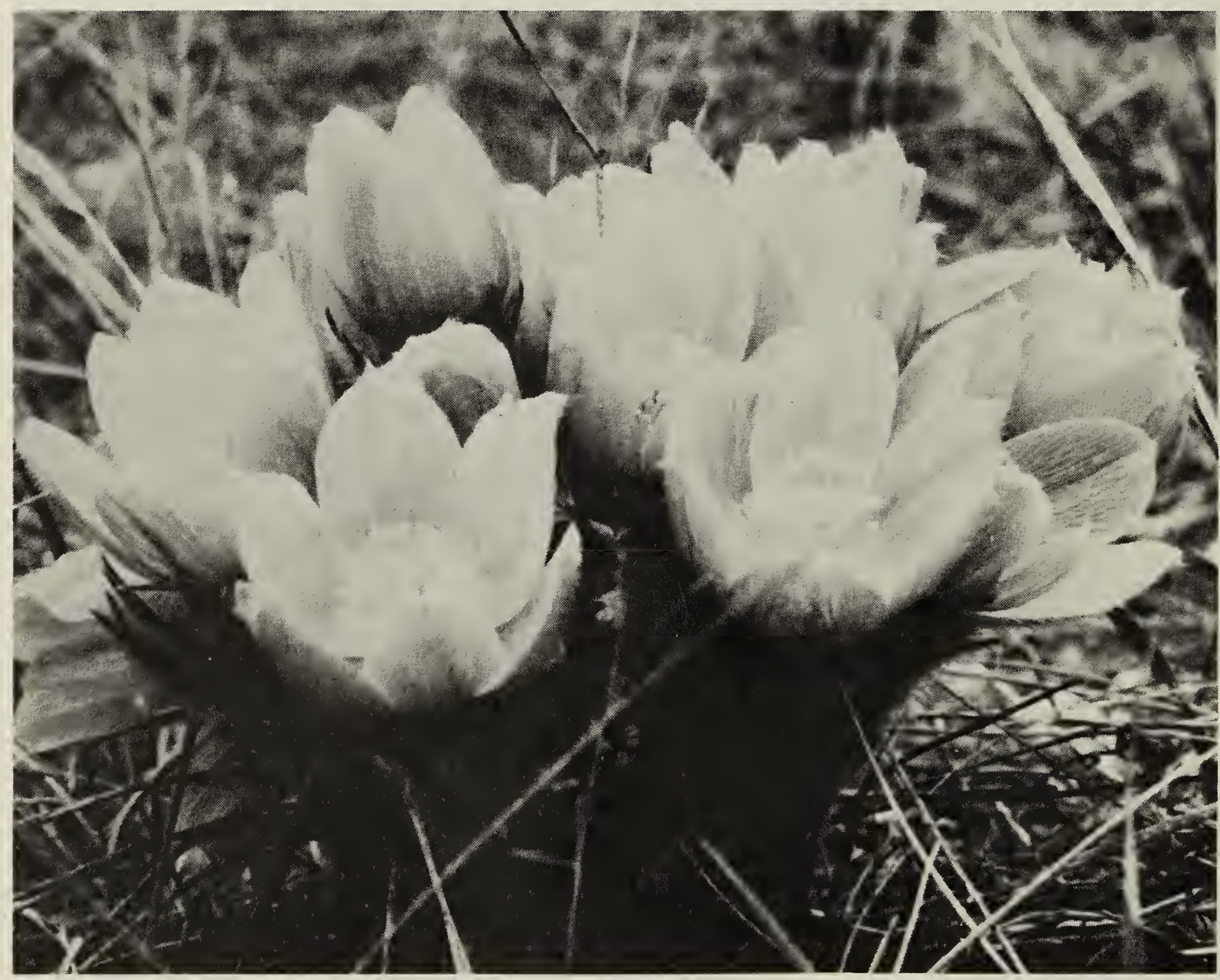

